\title{
Management Increasing competitiveness of local beef for the forest fringe communities
}

\author{
Toni Herlambang ${ }^{1}$, Teguh Hari Santosa ${ }^{2}$, Nurul Qomariah ${ }^{3}$, Oktarina $^{4}$ \\ 1,3 Department of Management, Economic Faculty, Muhammadiyah University of Jember \\ ${ }^{2,4}$ Department of Agriculture, Agriculture Faculty, Muhammadiyah University of Jember
}

\begin{abstract}
Competitiveness of local cattle forest fringe communities is generally low, which resulted in weak local economy. Efforts to improve the competitiveness of the local cows will strengthen the local economy through improved cultivation technology, market structure, industry structure and demand conditions of the local cows.. Specific target in this research is to formulate a model improving the competitiveness of local cattle in an attempt to strengthen the economy of forest fringe communities. The results showed that (1) cattle breeders in the study site in Jember District generally is a model "gaduhan "(the result is divided in two) Local cattle owners were actually better kind of cattle Bali and Madura cattle generally maintain beef cattle with an average tenure 2-8 tails. (2) the competitive and comparative competitiveness of local beef cattle types Bali is high as indicated by the PCR values 0.4261 and 0.4397 DRCR. Madura local beef cattle types also have high competitiveness competitive PCR value 0.3679, but the comparative competitiveness is quite high with DRCR 0.5135. (3) Average profit local cattle rancher (cattle types of Bali and Madura) with the scale 2-8 44.115.638/tail/year or tails of $R p R p$ 3.676.303tailr/month or greater than the minimum wage on Jember (Rp $1,200,000)$, and contribute to the family income by $53.96 \%$. (4) There are six production facilities required to enhance the competitiveness of local cattle, namely human resources, technology, capital, raw materials, machinery and markets.
\end{abstract}

Key words: local beef cattle types of Bali and Madura cattle, high competitiveness

\section{Introduction}

Local cattle as one of the national commodity has the potential competitiveness can be improved through profitability and market share. Trigger factor consists of competitiveness are technology, productivity, and input costs, industry structure and demand conditions (Rahman et al., 2007). Efforts to improve the competitiveness of local cows will strengthen the national economy through the improvement of society as a cultivation technology (including improved productivity, quality, and cost of inputs), the management structure of the market, industry structure and demand conditions for local cattle. The main center for the production of beef cattle (including cattle locally) in Java accounted for $45 \%$ of national beef production (Mersyah, 2005). Local beef production potential and competitiveness could still be improved to catch Indonesian society needs meat consumption at $4.5 \mathrm{~kg} /$ capita / year (Safitri, 2012).

The results of previous studies by Herlambang et al. (2007-2008) and Herlambang et al (2011-2012) found that the quality and productivity of local cattle is generally low, the causes include: (a) local cattle as a sideline business less attention to the cultivation of the right technology; (b) lack of fodder technologies; (c) lack of market structure and administration of local cattle; (d) lack of quality control at every stage of meat production to processing. This resulted in a weak economy local cattle rancher on the outskirts of the forest and threatening the conservation of forests, because it triggers their desire to explore the forest.

The specific objective of this study is to formulate a model improving the competitiveness of local cattle in an attempt to strengthen the economy of forest fringe communities.

\section{Research methods}

The approach used in this study is a participatory approach. participatory approaches (qualitative) is more geared to deepening grounded interesting case is termed as a model supporting ICLC (Increased Competitiveness local cows) for forest fringe communities into research outcomes. Location research purposively in Jember because this area includes areas that generate enough local cattle (237,602 head) in East Java Province, and selected the District Sumberjambe (17,287 head), Silo (15 730 tail), Tempurejo (11,941 head) and Subdistrict Gumukmas (11 079 tail), because in this region as the biggest producer of local cattle (BPS, 2012).

The samples (respondents) conducted by stratified random sampling or stratified random, given that households living in the outskirts of the forest as the population consists of a group is quite heterogeneous. Stages of selection of respondents is as follows: (1) hold a population stratification, which classifies the population into homogeneous groups seen from the types of jobs and economic activity; (2) the selection of 
respondents performed after obtaining population stratification, ie each stratum in this study were taken 10 to 30 people in every district at random.

Sources of data in this study grouped by types of data (including primary and secondary data). Sources of primary data obtained from interviews and direct observation in the field. Sources of secondary data obtained from the relevant agencies. Data collection techniques in this study in addition to using the Participatory Rural Appraisal (PRA) and Focus Group Discussion (FGD), also using the method of rapid rural appraisal (RRA), indept interview and survey. Analysis using quantitative and qualitative analysis. Quantitative analysis related to the competitiveness of the local cows approached the analysis of comparative and competitive advantages with DRCR calculation (Domestic Resource Cost Ratio) and PCR (Private Cost Ratio) (Agustian, 2007). Qualitative analysis selected is tendency phenomenological analysis and pattern done throughout the study period using FGD analysis, RRA, PRA.

\section{Results}

The main target of improving the competitiveness of the model is an attempt to overcome the drawbacks of existing facilities in the agribusiness cows with supporting sub-systems involving related. Agribusiness sub-systems in this model begins with a sub-system of farming that is influenced by internal and external factors. Internal factors relate to land and production factors. Problems of land to feed local cattle located between the slope of the land is prone to landslides and fertility is threatened due to lack of proper fertilization and lack of organic fertilizer. Regarding the availability of factors of production that are less fulfilled, such as: natural resources diminishing quality, poor quality of human resources managers / ranchers, and limited capital to finance the feed and obtain seeds.

While external factors, including the selling price of local beef, beef imports and the existence of environmental problems / ecology. The presence of cattle imports of better quality can be a contender local cattle that can affect the selling price of local beef. If the local cattle prices low will reduce the interest of farmers to manage their farming well. Environmental and ecological issues are less supportive of growth and development of plants can threaten the existence of local cattle.

Six a means that need to be addressed at the local cattle agribusiness more easily known as $6 \mathrm{M}$, namely: method / way (technology), money / capital, men / human resources, materials (raw materials), machinery, and the market (the market).

\section{Human Resources}

Efforts to improve the quality and ability of farmers is absolutely necessary to improve the performance of local cattle agribusiness. Increasing the ability of farmers can be made by many parties and how. Way never done is Field School (FS), which has been done up to the advanced stage of the field by trainers and other experts who care for the breeder. But unfortunately only $5 \%$ of farmers who ever followed.

Thereby increase in the ability of models breeders still needed to equip farmers with a variety of skills, both technical and management, so that the competitiveness of local cattle performance can be achieved. In addition to the technical and managerial capabilities, other things are also needed to improve the quality of the breeder is a change in mindset and behavior in farming. In terms of the mindset of farmers should be made aware of many things such as: not easily tempted bonded labor system, the importance of cooperation among farmers to become members of the groups, the importance of improving efficiency and productivity, the importance of avoiding adverse debt system and others. Without the mindset that good breeders will not behave so well in farming technology and available capital will not be used optimally.

\section{Method / way (technology)}

The results showed that the average productivity of local cattle is low so that the necessary technology at the farm level is the local cattle weight gain by using seeds, animal feed use as directed and use of natural resources in the surrounding area to make organic fertilizer.

The use of organic fertilizers should be encouraged at the local cattle ranch for two purposes, namely: (1) can improve soil structure and texture for cattle grazing land; and (2) increase the income of farmers selling local cow manure (organic fertilizer). In addition to cultivation techniques breeder should also be made aware of the importance of harvest and post-harvest technology of local cattle ideal for cattle prices in order to increase the income of local cattle ranchers.

\section{Money / capital}

Capital required as working capital and investment. Although not absolute, the capital needed to finance better technology at a local cattle agribusiness. Working capital needed for farming cows per cow in Jember based research is $\mathrm{Rp} 3.500 .000$ - Rp 4,000,000 for the purchase of cows. Referring to the results of the analysis of the advantages of farming and cattle contribute to the family income is seen that the local beef is still 
not able to meet the needs of the whole family for cattle farmers, so it can be understood that farmers often find it difficult to obtain working capital. Therefore the required cooperation with financial institutions / banks to local cattle farmers have the opportunity to obtain a soft loan for working capital.

Cooperation with financial institutions is not easily done by farmers individually because of small collateral owned by the farmer. Some ranchers are forced to sell their products to the urgent need at a low price through a system of debt bondage, or borrow the money lenders at high interest rates. It required the parties or some credible financial institution as a loan guarantor breeder. Institutions may trustworthy accompanied by extension farm farmer groups, as is done by the extension workers and farmer groups in Sub Gumukmas Cows were successfully obtained credit from Bank Indonesia of 1.2 billion to finance agribusiness local cows in the group.

Another example is an exporter which acts as a source of farmer groups avalist for "Sumber Kembang", "Sudi Makmur" and "Surya Tani"subdistrict Sumberbaru who managed to obtain a loan of 1 billion to provide working capital for 250 farmers amounting to Rp 4,000,000.per groups. Sub-system of post-harvest handling and processing of the results requires a substantial investment for the procurement of building enclosure, animal feed and operational costs. Without the help of the supporting sub-system is difficult for farmers and farmer groups even have their own feed processing units due to their limited capital.

\section{Materials (raw materials)}

The quantity, quality and continuity of raw materials is very important to note the treatment process. Less quantity will affect the smoothness of the production process, whereas if the excess will not be handled, the quality will affect the quality standard of the final result, while keeping the continuity is the continuity of the process and will support the achievement of production targets.

To illustrate the importance of maintaining the quantity, quality and continuity of feed ingredients can be put forward examples of Cattle Farmers Group in District Gumukmas. The group has managed to operate the machine if the supply of feed and animal feed ingredients should be quality standards as much as 24 tons per month of continuous. To meet the capacity of farmer groups is already schedule fodder processing time for each of its members, and with the proactive system using a simple means of transportation to take directly to the location of the breeder, so the availability and amount of raw materials is always fulfilled. In the process of postharvest handling of local beef, raw material availability problems of local cattle has led to the convening of the process if it can not beef by other farmer groups, although it is known that if the beef promises greater profits than selling live cattle.

\section{Machinery / equipment}

Machine is one of the technologies necessary to facilitate the work and improve efficiency and productivity. There are many types of machinery required in support of local cattle agribusiness. The machine that is now familiar among breeders is handling animal feed and industrial processing machinery downstream of cattle (beef), which is obtained either on their own initiative and effort as well as government assistance. Some machines have been able to run well and very helpful breeders, but some still have not been utilized. example:

1. Some farmer groups receive a set of downstream processing machines can not use it due to some problems, such as: raw materials, human resources will run the business, operational costs to marketing.

2. A cooperative farmer groups to temporarily halt the processing of a set of feed processing machine from East Java provincial government assistance because they have not found the reason why processed products not meeting quality standards.

\section{Market}

The market is the last estuary of every business, including agribusiness. The market became the main attraction for the farmer to try. The market is wide open and high prices will add to the spirit of farmers to plant certain commodities, the opposite conditions will dampen the spirit. Even at the local cattle, if the market does not tend to improve some local cattle breeders will replace with other, more profitable businesses. There are two kinds of products that can be marketed ranchers, the cattle Bali and Madura cattle. Bali cattle market behavior at the farmer level is oligopsony market, which is only a few buyers with many breeders as a seller. In deciding oligopsony market price is a buyer and breeder just price takers who do not have the power to determine the price. This condition is exacerbated when farmers are in need of money so eager to sell their products.

The structure of the local cattle market at a very modest level of farmers, from farmers directly to collectors $(100 \%)$ for local cattle, and directly to the cooperatives $(50 \%)$ or hand wholesalers $(50 \%)$ for local cattle. By ignoring the weakness of monopsony market behavior, market structure is simple cause marketing efficiency breeder cows in the high level. Marketing efficiency is the ratio between the cost of marketing the product value, is one measure of marketing performance. 
The lower the value, the higher the efficiency of marketing, meaning the higher the performance of the market. Judging from the ratio of the cost of marketing and selling the value of local cattle, cattle market performance at the farm level can be said to be very high because the average marketing costs incurred very small breeder. Most local farmers market their cattle through the mediator approached directly by the buyer to the location of the breeder. While other local cattle directly accommodated cooperatives, and the market through wholesalers are accommodated in the collector if it deems it meets the required standard.

The difference between local cattle are marketed through cooperatives and directly to wholesalers is the quality of the local cattle farmer cooperative groups are relatively uniform because relatively strict supervision. The tight supervision because the cooperative has been under contract with wholesalers so that should keep the trust carefully. Local cattle market structure is sometimes also more complicated due to the consumer to have to go through several marketing agencies. Market breakthrough has been tried by a cooperative that offers local beef products with various types of farmer groups at the cooperative office. Fostering of sixth facilities agribusiness local cattle is expected to improve the competitiveness, profitability and contribution to the family income of farmers. Further indicators of competitiveness, profitability and contribution to the family income of farmers will be feedback and evaluation materials to see which would still require further development and which parts need to be maintained.

\section{Competitiveness of Local Cattle (Bali Cattle and Madura Cattle) in Jember}

Competitive and comparative competitiveness of local beef cattle types Bali is high as indicated by the PCR value of 0.4261 and 0.4397 DRCR. Madura local beef cattle types also have high competitiveness on the PCR value of 0.3679, but the comparative competitiveness of Madura cattle is quite high with DRCR 0.5135. Average profit local cattle rancher (Bali and Madura cattle types) with the scale 2-8 tails of Rp 44,115,638 /

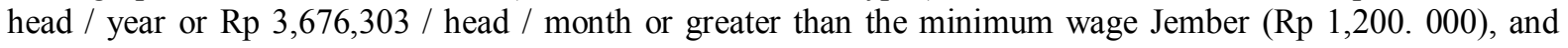
contribute to the family income by $53.96 \%$.

\section{Conclusions}

Cattle farmers in the study sites in Jember District (the District Sumberjambe, Silo, Tempurejo and District Gumukmas) generally is "gaduhan" models (Profit Sharing). Local cattle owners were actually better kind of cattle Bali and Madura cattle beef cattle generally maintaining an average tenure with 2-8 tails.

1. Competitive and comparative competitiveness of local beef cattle types Bali is high as indicated by the PCR value of 0.4261 and 0.4397 DRCR. Madura local beef cattle types also have high competitiveness on the PCR value of 0.3679 , but the comparative competitiveness is quite high with DRCR 0.5135 .

2. Average profit local cattle rancher (Bali and Madura cattle types) with the scale 2-8 tails of Rp 44,115,638 / head / year or Rp 3,676,303 / head / month or greater than the minimum wage Jember (Rp 1,200.000), and contribute to the family income by $53.96 \%$.

3. There are six production facilities are needed to enhance the competitiveness of local cattle, namely human resources, technology, capital, raw materials, machines and markets.

\section{Recommendations}

In a subsequent study, need to test the reliability of the model increase the competitiveness of local cattle in an effort to strengthen the local economy on the forest fringes wider scale that some districts in East Java Province and several provinces in Indonesia to strengthen economic model in the framework of forest fringe communities.

\section{References}

[1]. Agustian, A. 2007. Daya Saing dan Profil Produk Agroindustri Skala Kecil (Kajian di Propinsi Lampung). Prosiding Seminar Nasional Teknologi Inovatif Pasca Panen untuk Pengembangan Agroindustri Berbasis Pertanian. Balai Besar Penelitian dan Pengembangan Pascapanen Pertanian. Hal. 979 - 989.

[2]. BPS, 2012. Jember dalam Angka. Kerjasama Badan Perencana Pembangunan Kabupaten Jember dengan BPS Kabupaten Jember.

[3]. Herlambang, T.; N. Qomariah; T.H. Santoso, dan Oktarina. 2007-2008. Analisis Keuntungan Usahatani Sapi Lokal di Propinsi Jawa Timur. Fakultas Ekonomi. Universitas Muhammadiyah Jember. Jurnal Ekonomika (Jurnal Ilmu-ilmu Ekonomi). Vol. 3, No.2, 2008 .

[4]. Herlambang, T.; N. Qomariah; T.H. Santoso dan Oktarina. 2011-2012. Analisis Mutu dan Produktivitas Sapi lokal pada Masyarakat Pinggiran Hutan di Kecamatan Ledokombo, Jember dan Kecamatan Grujugan, Kabupaten Bondowoso. Jurnal Agritrop (Jurnal Ilmu-ilmu Pertanian). Vol. 7, No.1, 2012.

[5]. Mersyah, R. 2005. Desain Sistem Budidaya Sapi Potong Berkelanjutan untuk Mendukung Pelaksanaan Otonomi Daerah di Kabupaten Bengkulu Selatan. Disertasi. Sekolah Pascasarjana, Institut Pertanian Bogor.

[6]. Priyanto, D. 2011. Strategi Pengembangan Usaha Ternak Sapi Potong dalam Mendukung Program Swasembada Daging Sapi dan Kerbau Tahun 2014. Jurnal Litbang Pertanian, Vol. 30, No. 3, 2011. pp. 108-116.

[7]. Rahman, R., A. Nuhung, dan M. Rachmat. 2007. Studi Pengembangan Sistem Agribisnis Perkebunan Lokal dalam Perspektif Globalisasi Ekonomi. Makalah Seminar Hasil Penelitian. Puslitbang Sosek Pertanian. Bogor.

[8]. Safitri. 2012. Mewujudkan Swasembada Daging 2014 sebagai Kontribusi Peternakan Berbasis Sumberdaya Lokal. WordPress.com. 